\title{
Telomerase RNAs of different ciliates have a common secondary structure and a permuted template
}

\author{
Joachim Lingner, Laura L. Hendrick, Thomas R. Cech \\ Howard Hughes Medical Institute, Department of Chemistry and Biochemistry, University of Colorado, Boulder, Colorado \\ 80309-0215 USA
}

Telomerase is composed of protein and RNA. The RNA serves as a template for telomere DNA synthesis and may also be important for enzyme structure or catalysis. We have used the presence of conserved sequence elements in the promoter and template regions to amplify by PCR the telomerase RNA genes from six different hypotrichous ciliates: Oxytricha nova, Oxytricha trifallax, Stylonychia mytilis, Stylonychia lemnae, Euplotes aediculatus, and Euplotes eurystomus. RNaseH cleavage of the O. nova RNA in extracts by use of a complementary oligonucleotide leads to loss of telomerase activity, supporting the identification. Primary sequence and biochemical experiments suggest that the templates of Oxytricha and Stylonychia are circularly permuted relative to that of $E$. aediculatus. On the basis of the pause sites, the former two add $G_{4} T_{4}$ during a single primer elongation cycle, whereas $E$. aediculatus adds $G_{3} T_{4} G$. The only primary sequence element outside the template that is conserved between these phylogenetically distant telomerase RNAs is the sequence $5^{\prime}$-(C)UGUCA-3', which precedes the template regions by exactly two bases. We propose a common secondary structure model that is based on nucleotide covariations, a model which resembles that proposed previously for tetrahymenine telomerase RNAs.

[Key Words: telomerase; telomere; secondary structure; phylogeny; polymerase; ribonucleoprotein]

Received April 22, 1994; revised version accepted June 29, 1994.

Telomeres, the physical ends of eukaryotic chromosomes, are essential for chromosome stability and contribute to chromosome organization within the nucleus (for review, see Zakian 1989; Blackburn 1991; Gilson et al. 1993). They typically consist of simple repetitive sequences rich in $\mathrm{G}$ residues in the strand that runs $5^{\prime}$ to $3^{\prime}$ toward the chromosomal end (e.g., $\mathrm{T}_{2} \mathrm{G}_{4}$ in Tetrahymena, $\mathrm{T}_{4} \mathrm{G}_{4}$ in Oxytricha, $\mathrm{T}_{2} \mathrm{AG}_{3}$ in humans). Telomeric DNA is of variable length, ranging from tens of base pairs in hypotrichous ciliates to a few hundred in yeast, to hundreds of kilobases in mammals (Klobutcher et al. 1981; Shampay et al. 1984; Moyzis et al. 1988; Kipling and Cooke 1990).

Because most DNA polymerases require a template and an RNA primer, it is expected that telomeres would become shorter with each round of DNA replication (Watson 1972). A mechanism for the complete replication of telomeres, involving the non-DNA-templated addition of telomeric repeats to the chromosome ends, was first identified in Tetrahymena by Greider and Blackburn (1985). The enzyme that carries out telomere extension is called telomere terminal transferase or telomerase (for review, see Blackburn 1992, 1993). It is a ribonucleoprotein with an essential RNA moiety (Greider and Blackburn 1987). Telomerase RNA genes have been cloned from various Tetrahymena species, Glaucoma chattoni (another tetrahymenine ciliate), and $E u$ - plotes crassus (Greider and Blackburn 1989; ShippenLentz and Blackburn 1990; Romero and Blackburn 1991); telomerase activity in Oxytricha nova and mammalian cells also requires an RNA subunit (Zahler and Prescott 1988; Morin 1989; Prowse et al. 1993). In Tetrahymena the telomerase RNA was shown to serve as a template for telomere DNA synthesis in vivo (Yu et al. 1990). Other roles for this RNA in telomerase structure or directly in catalysis remain speculative.

The biological functions of stable RNAs depend on their secondary and tertiary structure. Comparative sequence analysis has proven very powerful for the elucidation of RNA structures. In this approach homologous RNA molecules from phylogenetically diverse organisms are sequenced and aligned. Base pairs are identified by compensatory base changes that maintain complementarity (for review, see Pace et al. 1989; Woese and Pace 1993). By use of this approach, Romero and Blackburn (1991) compared seven tetrahymenine telomerase RNA sequences and proposed a common secondary structure.

We and others are studying telomere structure and function in the hypotrichous ciliate Oxytricha nova (Gottschling and Cech 1984; Gottschling and Zakian 1986; Price and Cech 1987; Hicke et al. 1990; Gray et al. 1991; Fang et al. 1993). The macronucleus of this organism contains $\sim 24,000$ different gene-sized chromosomes 
each present in 1000 copies on average. The telomerase RNA from another hypotrichous ciliate, Euplotes crassus, is longer and, apart from the template region, shows no primary sequence similarity to the tetrahymenine telomerase RNAs (Shippen-Lentz and Blackburn 1990). Thus, alignment with the tetrahymenine telomerase RNAs could not be made with confidence. This supports the large evolutionary distance between hypotrichs and Tetrahymena, which is comparable to that separating the rat from maize or Chlamydomonas (Fig. 1).

To learn more about the structure of telomerase RNAs, we have cloned the telomerase RNA genes from Oxytricha nova, Oxytricha trifallax, Stylonychia mytilis, Stylonychia lemnae, Euplotes aediculatus, and Euplotes eurystomus and have developed a model for their secondary structure. This model is compatible with that of tetrahymenine telomerase RNAs proposed by Romero and Blackburn (1991), indicating structural conservation over large evolutionary distances. Primary sequence and biochemical experiments furthermore indicate that the templates of Oxytricha and Stylonychia telomerases are permuted with respect to that of $E$. aediculatus. The former two appear to use the sequence 5'-AAAACCCC$3^{\prime}$ as a template for $5^{\prime}$-TTTTGGGG-3' telomeric repeat synthesis, whereas the latter uses the sequence $5^{\prime}$ CAAAACCC-3'. This supports the mechanistic model of telomerase involving primer annealing, primer elongation, and translocation (Greider and Blackburn 1989).

\section{Results}

\section{Cloning of telomerase RNA genes}

We used a PCR strategy to clone the telomerase RNA genes from six hypotrichous ciliates. Four sequence elements were expected to be present on the macronuclear

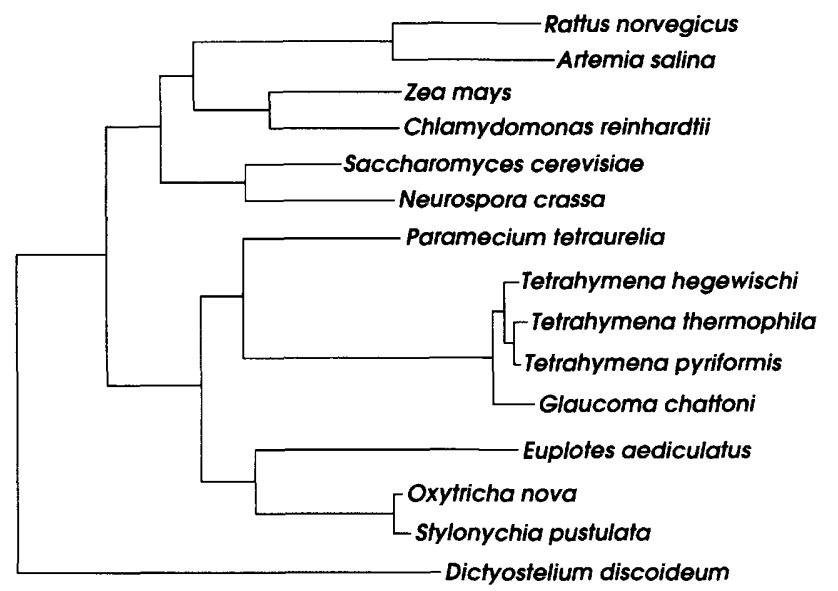

0.05

Figure 1. Ciliate phylogeny inferred from small rRNA sequence similarities (Greenwood et al. 1991). The evolutionary distance is based on the average number of nucleotide replacements per sequence position and is represented by the horizontal component separating species in the figure. The scale bar equals 0.05 nucleotide replacements per sequence position. chromosomes encoding telomerase RNA: the telomeric sequences at each chromosomal end, a sequence providing the template for telomere synthesis similar to the one identified in $E$. crassus (Shippen-Lentz and Blackburn 1990), and an 8-bp promoter element (Fig. 2) present in all telomerase RNA genes sequenced so far (Romero and Blackburn 1991). DNA oligonucleotides were designed to hybridize to these sequence elements. With these oligonucleotides as primers and nuclear DNA as template, we attempted to amplify telomerase RNA gene-specific DNA fragments (see Materials and methods for primer sequences and other details). Certain positions of the DNA oligonucleotides were made degenerate to increase the chances of annealing. Amplified DNA fragments were analyzed by gel electrophoresis and sequenced. The sequences of amplified fragments served as the basis for the design of new DNA oligonucleotides that were used in further PCR amplifications.

As a representative example, the cloning strategy for the $O$. trifallax telomerase RNA gene is described in more detail: The gene was first amplified between promoter and telomerase template with the promoter-specific primer T8T and the template-specific primer T20. Subsequent sequence information was used for the design of T25, an oligonucleotide with sense orientation corresponding to sequences close to the template. The $3^{\prime}$ half of the gene was then amplified with T25 and Telpr, an oligonucleotide that was designed to anneal at telomeres of macronuclear DNA. To confirm the obtained sequence information, the transcribed region of the telomerase RNA gene was amplified, subcloned and sequenced again in separate PCR amplifications with two oligonucleotides (T37 and T38) that flanked the gene.

For $O$. nova the $3^{\prime}$ portion of the gene was amplified first, with an oligonucleotide (T27) that was based on the O. trifallax telomerase RNA sequence and the telomerespecific primer Telpr. Amplification of the 5' half of the $O$. nova gene from nuclear DNA was unsuccessful. Therefore, nuclear RNA was isolated and reverse transcribed in the presence of an oligonucleotide (T33) designed to hybridize to telomerase RNA (position 109 to 91). The resulting cDNA was dG-tailed at the $3^{\prime}$-end with terminal deoxynucleotidyl transferase, PCR-amplified with the telomerase-specific primer (T33) and a dGtail specific primer (T15), and sequenced. In one case $(E$. eurystomus), an inverse PCR strategy was used to obtain the sequence information of the entire telomerase RNA (see Materials and methods).

O. nova, O. trifallax, S. lemnae, S. mytilis, and $E$. aediculatus were found to have, excluding telomeric sequences, 183-, 156-, 180-, 165-, and 192-bp untranscribed trailers, respectively. The entire $5^{\prime}$-untranscribed leader sequences between telomere and gene were obtained only for $S$. mytilis and E. eurystomus and, excluding the telomeric sequence, are 315 and 592 bp long, respectively.

\section{Verification of the identity of cloned telomerase RNA genes}

To confirm the identity of the cloned O. nova telom- 
Figure 2. Sequence alignment and consensus of putative telomerase RNA promoter elements. Highly conserved regions are boxed. The transcriptional start site is indicated by the arrow. Gaps introduced within the alignment are indicated by dots. The E. crassus sequence is from Shippen-Lentz and Blackburn (1990). The $T$. thermophila and Glaucoma chattoni sequences are from Romero and Blackburn (1991). Abbreviations: USE, upstream sequence element; O.n., O. nova; O.t., O. trifallax; S.l., S. lemnae; S.m., S. mytilis; E.a., E. aediculatus; E.e., E. eurystomus; E.c., E. crassus; T.t., T. thermophila; G.c., G. chattoni.

erase RNA gene, we utilized a method whereby telomerase present in nuclear extracts is inactivated by targeted cleavage of its RNA moiety. RNaseH is a nuclease that cleaves only the RNA strand in a DNA:RNA heteroduplex. By use of specific DNA oligonucleotides and RNaseH it is possible to target an RNA present in an RNP very specifically, as long as the RNA is available for hybridization (Krämer et al. 1984; Greider and Blackburn 1989|. We therefore assayed for inactivation of OXytricha telomerase by DNA oligonucleotides /complementary to different portions of the sequence determined for telomerase RNA; Fig. 3A) in the presence of RNaseH.

Following RNaseH treatment, telomerase activity was tested in two different assays (Fig. 3B,C), and telomerase RNA was analyzed by Northern blots (Fig. 3D) and reverse transcription (data not shown). In Figure 3B, samples of nuclear extract $(0.5 \mu \mathrm{l}$ and $1.5 \mu \mathrm{l}$ in each pair of lanes) were analyzed for their ability to extend nanomolar amounts of $5^{\prime}$-end labeled $\left(\mathrm{T}_{4} \mathrm{G}_{4}\right)_{2}$ in the presence of dGTP and dTTP. Preincubation of extract at $30^{\circ} \mathrm{C}$ with a nonspecific oligonucleotide led to a considerable decrease in activity (cf. untreated extract in lanes 2 and 3 with preincubated extract in lanes 4 and 5). Incubation of extract with oligonucleotides R1 and R4, both of which are complementary to the telomerase RNA, did not result in any specific further decrease of activity. However, preincubation of extract with R2 and R3 caused a further reduction and complete inhibition of activity, respectively. $\mathrm{R} 2$ is complementary to the region $3^{\prime}$ of the template and R3 is complementary to the template region itself.

Telomerase activity was also tested in the presence of unlabeled $\left(\mathrm{T}_{4} \mathrm{G}_{4}\right)_{2}$, dGTP and $\left[\alpha^{-{ }^{3}} \mathrm{P}\right]$-labeled dTTP (Fig. $3 \mathrm{C}$. In this assay any extended oligonucleotide becomes visible as a result of the incorporation of radiolabeled dTMP. Again, preincubation of extract with R2 and R3 led to a partial and complete inhibition of activity, respectively. No additional bands with another pausing pattern were identified, which would have indicated the extension of the complementary oligonucleotides used in the RNase $\mathrm{H}$ treatment.

To test further whether inhibition of activity could be correlated with cleavage of the sequence we had identified as telomerase RNA, RNaseH-treated extracts were analyzed in Northern blots (Fig. 3D). A telomerase gene probe that covers the entire transcript hybridized to a single band 190 nucleotides in length in a Northern blot of nuclear RNA (lane 2). Telomerase RNA in extracts remained intact when preincubated with the nonspecific oligonucleotide Rco and with the telomerase-specific oligonucleotides R1 and R4 (lanes 3, 5, 11). However, denatured nuclear RNA was RNaseH-cleavable with R1 and $\mathrm{R} 4$ (lanes 4,10 ). This suggests that the regions corresponding to $\mathrm{R} 1$ and $\mathrm{R} 4$ are inaccessible for hybridization in the native RNP. With oligonucleotide R3, telomerase RNA was cleaved to completion, consistent with the observed complete inactivation of the enzyme. Preincubation of extract with $\mathrm{R} 2$ and $\mathrm{RNaseH}$ resulted in partial cleavage of telomerase RNA, which is consistent with the partial inactivation of the enzyme. Analysis of nuclear RNA by reverse transcription sequencing in an independent experiment confirmed that telomerase RNA becomes cleaved at positions that correspond to the oligonucleotide annealing sites (data not shown). We therefore conclude that the isolated gene corresponds to the telomerase RNA moiety of $O$. nova.

\section{Promoter elements and determination of telomerase RNA termini}

The $5^{\prime}$-end of the O. nova telomerase RNA was cloned by use of reverse transcription PCR as described in the first section of Results. Several independently generated clones were sequenced and most of these (12 out of 16) indicated that the mature RNA starts with the adenosine residue indicated in Figure 2. This might be a general feature of telomerase RNA transcripts because the 5'ends of Tetrahymena (Romero and Blackburn 1991) and Euplotes crassus (mentioned in Romero and Blackburn 1991) telomerase RNAs were also mapped to adenosine residues. Inspection of the upstream region (Fig. 2) furthermore shows that this adenosine residue is always preceded by a thymidine. Telomerase RNAs are thought to be pol III transcripts and additional common sequence elements in the $5^{\prime}$-untranscribed leader can be identified (Romero and Blackburn 1991; Fig. 2). The conserved region around position -50 (Upstream Sequence Element or USE) is also present in the upstream region of the Tetrahymena U6 gene (Ørum et al. 1992). A TATA-like element of loose consensus is found around position -25 .

The $3^{\prime}$-end of the O. nova telomerase RNA was also mapped. Total nuclear RNA was polyadenylated in vitro 

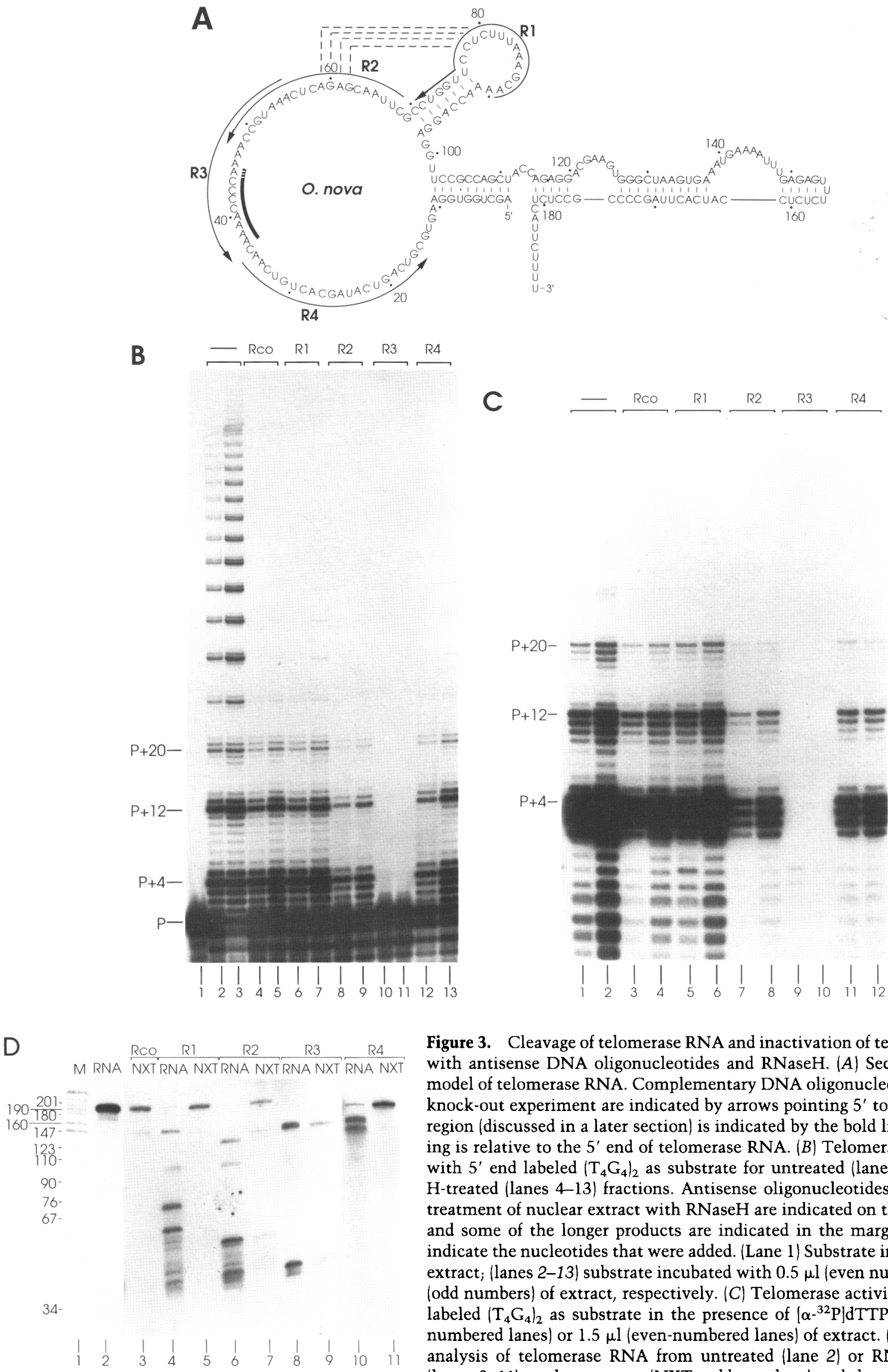

Figure 3. Cleavage of telomerase RNA and inactivation of telomerase activity with antisense DNA oligonucleotides and RNaseH. $(A)$ Secondary structure model of telomerase RNA. Complementary DNA oligonucleotides used in the knock-out experiment are indicated by arrows pointing $5^{\prime}$ to $3^{\prime}$. The template region (discussed in a later section) is indicated by the bold line. The numbering is relative to the $5^{\prime}$ end of telomerase RNA. $(B)$ Telomerase activity assay with $5^{\prime}$ end labeled $\left(\mathrm{T}_{4} \mathrm{G}_{4}\right)_{2}$ as substrate for untreated (lanes 2,3) and RNase $\mathrm{H}$-treated (lanes 4-13) fractions. Antisense oligonucleotides used in the pretreatment of nuclear extract with $\mathrm{RNaseH}$ are indicated on the top. Primer $(\mathrm{P})$ and some of the longer products are indicated in the margin. The numbers indicate the nucleotides that were added. (Lane 1) Substrate incubated without extract; (lanes 2-13) substrate incubated with $0.5 \mu \mathrm{l}$ (even numbers) and $1.5 \mu \mathrm{l}$ (odd numbers) of extract, respectively. $(C)$ Telomerase activity assay with unlabeled $\left(\mathrm{T}_{4} \mathrm{G}_{4}\right)_{2}$ as substrate in the presence of $\left[\alpha-{ }^{32} \mathrm{P}\right] \mathrm{dTTP}$ and $0.5 \mu l$ loddnumbered lanes) or $1.5 \mu \mathrm{l}$ (even-numbered lanes) of extract. (D) Northern blot analysis of telomerase RNA from untreated (lane 2) or RNaseH pretreated (lanes 3-11) nuclear extract (NXT; odd numbers) and deproteinized nuclear RNA (even numbers), respectively. The blot was probed with a randomly labeled PCR product that covered the entire $O$. nova telomerase RNA gene. Antisense oligonucleotides used with RNaseH are indicated on the top. DNA marker fragments from pBR322 digested with HpaI (lane 1), with sizes (base pairs) indicated at the left. 
with yeast poly(A) polymerase isolated from recombinant Escherichia coli and reverse transcribed with an oligo (dT) primer. Telomerase RNA specific cDNA was then specifically amplified by PCR with a telomerase RNA-specific primer and the oligo (dT) primer. Amplified products were again subcloned and subjected to sequence analysis. The $3^{\prime}$-ends all consisted of either three or four $\mathrm{T}$ residues (three and two independent clones, respectively|. This seems to be a general feature of telomerase RNA, because the Euplotes crassus and Tetrahymena telomerase RNAs were also found to end with a stretch of $U$ residues. The telomerase RNA from $O$. nova therefore has a length of 189-190 nucleotides. On the basis of sequence alignment, the other hypotrich telomerase RNAs appear to have similar lengths of between 185-186 (O. trifallax) and 193-194 (E. crassus) nucleotides. Thus, the telomerase RNAs from the hypotrichous ciliates are considerably longer than those of Tetrahymena, which have lengths of around 160 nucleotides.

\section{Comparison of telomerase RNA primary sequences}

The six new telomerase RNA sequences were aligned with each other and with the E. crassus telomerase RNA sequence identified previously (Shippen-Lentz and Blackburn 1990). This comparison revealed that the primary sequences have diverged considerably, up to $50 \%$ (Table 1). The large distance between the Stylonychia and Oxytricha sequences compared to the E. crassus sequence is striking. Also, this salt-water species of Euplotes appears to be very distant from the two freshwater species, E. aediculatus and E. eurystomus.

The primary sequence alignment identified a few common sequence elements. Apart from the proposed template sequence, the most remarkable homology we observe is the sequence $5^{\prime}$-UGUCA-3'. This sequence is preceded by a $\mathrm{C}$ residue in all sequenced telomerase RNAs but that of T. pyriformis; it is found precisely two bases upstream from the $5^{\prime}$ boundary of the proposed template. This is the only sequence element common to all sequenced telomerase RNAs, including those of the Tetrahymena species. Some other sequence elements common to all hypotrichous ciliate telomerase RNAs are discussed below.

\section{A common secondary structure model}

To identify a common secondary structure, possible duplex regions were first identified in individual telomerase RNAs by use of the computer algorithm from Zuker (1989) with the thermodynamic parameters of Jaeger et al. (1989). Only duplexes that could also be readily identified in the homologous regions of the other telomerase RNA sequences were considered further. Compensatory base-pair changes that maintain pairing potential were taken as indicative of a true duplex. This initial analysis was used to refine the primary sequence alignment because bases that align in the secondary structure should also align in the primary sequence. An iterative procedure was then carried out, in which the refined primary sequence alignment was searched for common secondary structure. Figure 4 shows the proposed foldings of telomerase RNAs from the hypotrichous ciliates. Although derived independently, they closely resemble the structure proposed for the Tetrahymena RNA by Romero and Blackburn (1991) and modified by ten Dam et al. (1991), who identified the pseudoknot involving stem-loop III.

Figure 5 shows the individual stems with compensatory base-pair changes highlighted by asterisks. Duplex regions whose existence is supported by the presence of more than one compensatory base-pair change are shaded.

Stem I is of variable length and is supported by the presence of compensatory base-pair changes at four positions. The G.A A.G tandem mismatch present in stem I of $E$. aediculatus and E. eurystomus is an often encountered apposition (Gautheret et al. 1994) and is likely to be thermodynamically neutral. The free energy increment measured for a G.A A.G tandem mismatch is $-0.4 \mathrm{kcal} /$ mole with $\mathrm{C}-\mathrm{G}$ as closing base pairs, and $+0.5 \mathrm{kcal} /$ mole with A-U as closing base pairs in model RNA duplexes (SantaLucia et al. 1991; A. Walter and D. Turner, pers. comm.). The two base pairs at the base of the stem

Table 1. Pairwise comparison of telomerase RNA Sequences

\begin{tabular}{|c|c|c|c|c|c|c|c|}
\hline & O. $n$. & O.t. & S. 1 . & S. $m$. & E. $a$. & E.e. & E. c. \\
\hline O. nova & - & 0.86 & 0.81 & 0.80 & 0.59 & 0.59 & 0.52 \\
\hline O. trifallax & $162 / 24$ & - & 0.85 & 0.84 & 0.59 & 0.59 & 0.51 \\
\hline S. lemnae & $153 / 33$ & $159 / 27$ & - & 0.96 & 0.62 & 0.61 & 0.57 \\
\hline S. mytilis & $152 / 34$ & $157 / 28$ & $182 / 7$ & - & 0.62 & 0.62 & 0.56 \\
\hline E. aediculatus & $112 / 64$ & $111 / 63$ & $118 / 58$ & $117 / 59$ & - & 0.98 & 0.69 \\
\hline E. eurystomus & $111 / 65$ & $110 / 64$ & $116 / 60$ & $117 / 59$ & $186 / 3$ & - & 0.70 \\
\hline E. crassus & $100 / 76$ & $97 / 77$ & $108 / 68$ & $106 / 70$ & $132 / 50$ & $133 / 49$ & - \\
\hline
\end{tabular}

The upper right half gives similarity values $\mathrm{H}$ for pairwise comparisons as defined by Sogin et al. (1986).

$\mathrm{H}=$ matches $/($ matches + mismatches + gaps/2). Matches, mismatches, and gaps are based on the primary sequence alignment of all telomerase RNA sequences. The lower left half gives the absolute number of nucleotides that match in the alignment over the absolute number of mismatches.

Nucleotides that are aligned with gaps are not considered in the lower half. 

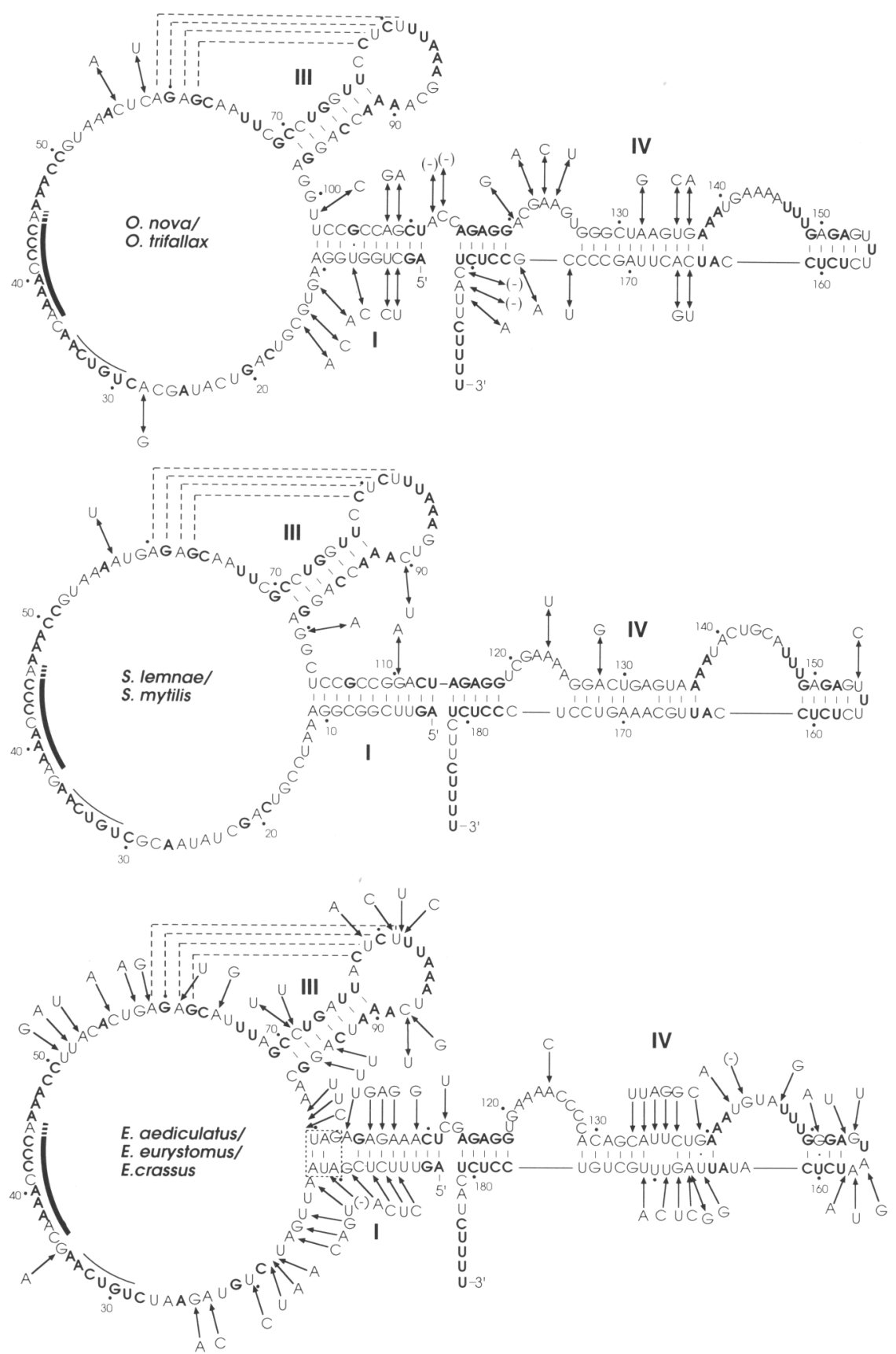

Figure 4. Secondary structure models of different telomerase RNAs. Four different genera are represented. Nucleotide exchanges within a genus are indicated by the arrows. For Euplotes the lines with single arrowheads indicate changes between $E$. aediculatus and E. crassus. Lines with arrowheads on both ends indicate changes between $E$. aediculatus and $E$. eurystomus. Bold residues indicate residues conserved within hypotrich telomerase RNAs or for the $T$. thermophila secondary structure within tetrahymenine telomerase RNAs, respectively. The possible pseudoknot structure of stem-loop III is indicated by dashed lines. The template is indicated by the bold line and the conserved 5 '-UGUCA-3' sequence by the thin line. Numbering of stems is according to Romero and Blackburn (1991). The T. thermophila telomerase RNA model is based on Romero and Blackburn (1991) as modified by ten Dam et al. (1991). The E. crassus sequence is from Shippen-Lentz and Blackburn (1990), but the structure is from the present work. Not all pairings are nominally proven by the criterion of two or more independent covariations in the complementary sequences of each stem (James et al. 1988). 

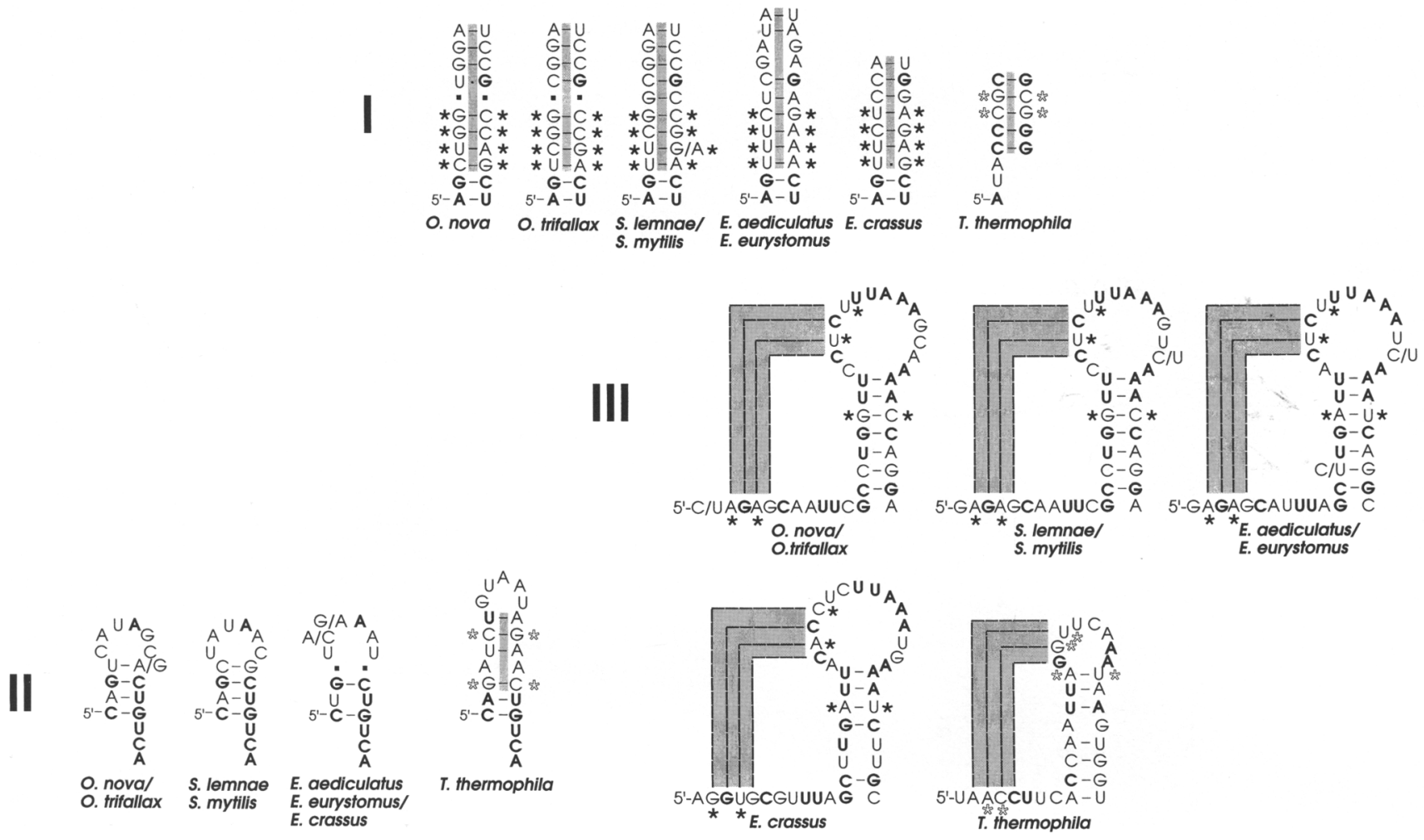

Figure 5. Representation of individual stems of telomerase RNAs. Base pairs that are supported by compensatory base-pair changes are indicated by asterisks loutlined asterisks for tetrahymenine telom. erase RNAs). Duplex regions that are proven by the criterion of two independent compensatory changes are shaded. Bold residues are as in Fig. 4. The left half of the internal loop below the top of stem IV has some pairing potential. The bold $\mathrm{A}$ - and U-residues could form a duplex with a U-A or a compensatory C-G (E. crassus) base pair at the top of the stem, thus leading to the formation of a hairpin loop containing two to five nucleotides.

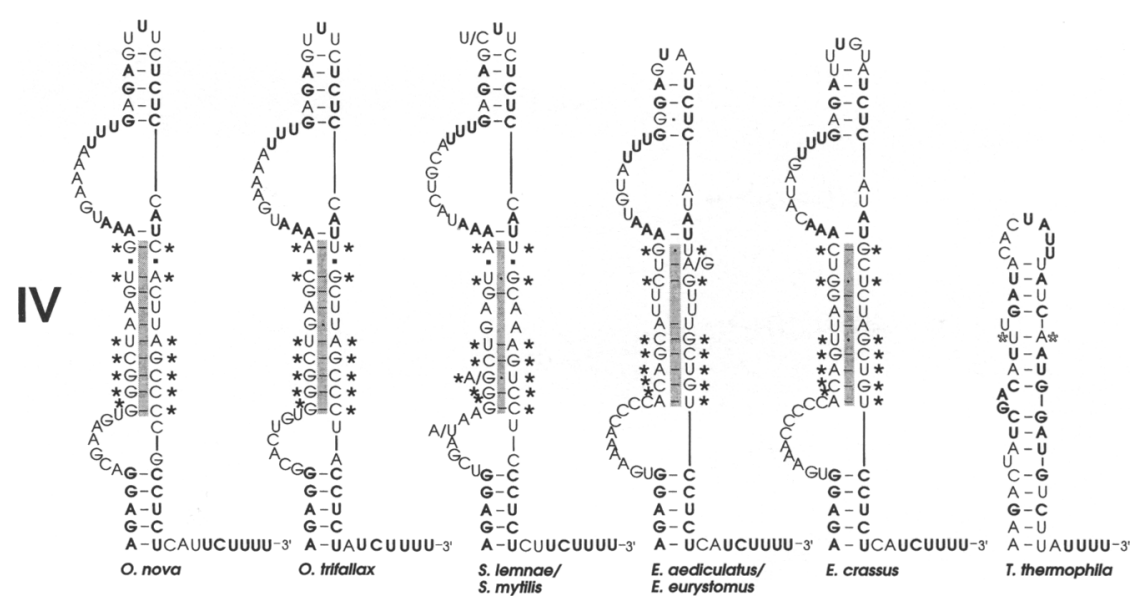

are invariant and therefore are not supported by comparative analysis.

The position of stem II is clearly identified in the primary sequences of all telomerase RNAs, because of its location relative to the invariant sequence element $5^{\prime}$ (C)UGUCA-3'. Stem II is supported for Tetrahymena by compensatory base-pair changes at two positions. A potential stem-loop structure can also be identified at this position in Oxytricha and Stylonychia. However, the three Euplotes species appear to be missing a thermodynamically stable stem II. We consider unlikely the possibility that the structure in this region is not conserved for all telomerase RNAs, because this region includes the invariant $5^{\prime}-(C)$ UGUCA $-3^{\prime}$ sequence. Therefore, we did not include stem II in our model.
Stem III participates in a pseudoknot downstream of the template region. The stem contains eight or nine base pairs, including only one compensatory base pair change. However, the identification of a stem at a similar position in Tetrahymena supports the existence of stem III. The U.U U.U tandem mismatch present in the E. crassus stem III is again thermodynamically not unfavorable $1-0.1 \mathrm{kcal} / \mathrm{mole}$ with $\mathrm{C}-\mathrm{G}$ as closing base pairs; SantaLucia et al. 1991). Two compensatory basepair changes provide good evidence for the pseudoknot involving the loop of stem III. Also notable is the conserved sequence $5^{\prime}$-UUAAA- $3^{\prime}$ present in the loop adjacent to the pseudoknot.

Stem IV can be subdivided into three or four smaller duplexed regions. The base of the stem consists of a com- 

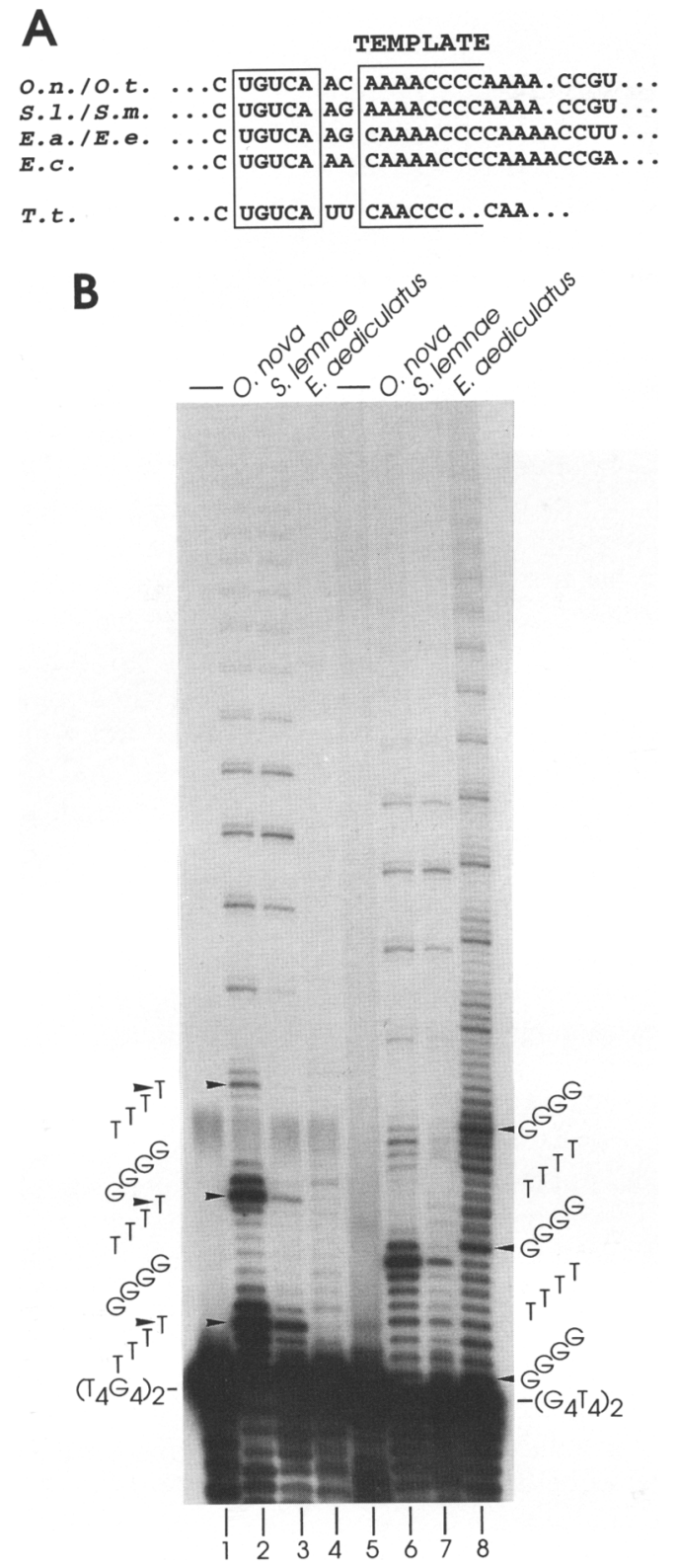

pletely conserved 5-bp duplex. Without compensatory mutations there is no phylogenetic evidence for its existence. However, it might be conserved because it is involved in a higher order structure, such as a triple helix or protein complex. The middle part of stem IV (shaded in Fig. 5) is manifest by compensatory base-pair changes at seven positions. The U.U U.U tandem mismatch present in E. aediculatus and E. eurystomus is reasonably stable in a duplex $(M$. Wu and $D$. Turner, pers. comm.). The G.A A.A tandem mismatch in Stylonychia is an often encountered apposition, suggesting that this sequence arrangement is nondisruptive (Gautheret et al. 1994). The top part of stem IV is again remarkably conserved, and thus not supported by comparative analysis.

\section{Permutations in the template}

The alignment of the telomerase RNA primary se-
Figure 6. Permutations within the templates of different hypotrich telomerase RNAs. (A) A portion of the primary sequence alignment of telomerase RNA, encompassing the template regions. The invariant 5'-UGUCA-3' element is boxed. The minimal template region is indicated by the open box. Species are abbreviated as in Fig. 2 and bold residues are as in Fig. 4. Dots between nucleotides represent gaps that were introduced to maximize matches between the different sequences when the entire sequences were aligned. $(B)$ Telomerase assay with $O$. nova, S. lemnae, and $E$. aediculatus (indicated on the top) nuclear extracts with two different 5 '-end-labeled oligonucleotide primers and unlabeled nucleoside triphosphates. The positions of the input primers $\left(T_{4} G_{4}\right)_{2}$ (lanes 1-4) and $\left(G_{4} T_{4}\right)_{2}$ (lanes 5-8), which could be clearly distinguished on the original autoradiograph, are indicated in the margins. Each sequence of added nucleotides indicated in the margin is inferred from the sequence of the corresponding primer and the sequence of the telomerase template region, and is supported by the fact that the dark bands (presumed pause sites) occur at constant positions within the repeated sequence. Further evidence for the sequence of the elongation products of $\left(\mathrm{G}_{4} \mathrm{~T}_{4}\right)_{2}$ in the case of $O$. nova is provided by dideoxy-GTP incorporation experiments reported by Zahler and Prescott (1988). Pause sites in the first few repeats are emphasized by the arrowheads.

quences reveals the presence of the sequence element $5^{\prime}-($ C)UGUCA-3' near the putative template. This sequence lies exactly two bases upstream of the $5^{\prime}$-end of the template of $T$. thermophila (Greider and Blackburn 1989; Autexier and Greider 1994) and E. crassus (Shippen-Lentz and Blackburn 1990). The sequence alignment (Fig. 6A) suggests that Oxytricha and Stylonychia use the sequence $5^{\prime}$-AAAACCCC- ${ }^{\prime}$ as a template for the synthesis of 5'-TTTTGGGG-3' telomeric repeats, whereas Euplotes uses the sequence 5'-CAAAACCC-3'. This contention is supported by the presence of a $G$ residue just upstream of the proposed boundary of the template in Stylonychia. This G would specify the addition of a C residue, which is not found in Stylonychia telomeres.

Circular permutation of the template is supported further by biochemical experiments. Primers that are elongated by telomerase show a very distinctive banding pattern when analyzed on sequencing gels. This banding pattern reflects the length of a telomeric repeat. It has been shown for Tetrahymena telomerase that the bands are most pronounced at positions within the repeat that correspond to the extreme 5 '-end of the template region (Autexier and Greider 1994). At this position the enzyme translocates to initiate another round of telomeric repeat synthesis (Greider and Blackburn 1989; Greider 1991; Autexier and Greider 1994). In Oxytricha, pausing is most pronounced after the addition of the fourth $\mathrm{T}$ in 5'-TTTTGGGG-3' telomeric repeats (Zahler and Prescott 1988). To compare the pausing patterns generated by different telomerases, we made nuclear extracts from $O$. nova, S. lemnae and E. aediculatus. Labeled oligonucleotides $\left(T_{4} G_{4}\right)_{2}$ and $\left(G_{4} T_{4}\right)_{2}$ were extended in telomerase assays and analyzed on a sequencing gel (Fig. 6B). With both primers it is clear that Oxytricha and Stylonychia 
telomerases give prominent elongation products that correspond to addition of the fourth $\mathrm{T}$ in $5^{\prime}$-TTTTGGGG-3' telomeric repeats, whereas $E$. aediculatus telomerase gives an accentuated product after adding the first $\mathrm{G}$ in $5^{\prime}$-TTTTGGGG-3' repeats. Therefore, Oxytricha telomerase is inferred to add 5'-GGGGTTTT-3' during each elongation cycle and that of $E$. aediculatus to add $5^{\prime}$-GGGTTTTG-3', as expected from the proposed $5^{\prime}$ boundaries of the templates.

\section{Evidence for 8- to 9-nucleotide-long templates}

The regular banding pattern observed in the population of products has a periodicity of one telomeric repeat. This is consistent with the current model for the mechanism of telomerase (Greider and Blackburn 1987) in which one telomeric repeat is added during each elongation cycle. Therefore the region normally used as a template for telomere synthesis in telomerase RNA has a length of one telomeric repeat as well (see previous section). The adjacent region is thought to position and align the primer. However, it was proposed for the $E$. crassus telomerase that under certain circumstances, the region of telomerase RNA used as template can be as long as 12 nucleotides (Shippen-Lentz and Blackburn 1990). This proposal stemmed from experiments in which oligonucleotides, which were complementary to the telomerase RNA and extended different numbers of nucleotides into the putative template region, were tested for their ability to serve as primers for telomerase. Because an oligonucleotide complementary to telomerase RNA that ended 13 nucleotides downstream of the 5 ' boundary of the template could prime telomere synthesis, it was concluded that the 12 nucleotides in between can serve as a template (Shippen-Lentz and Blackburn 1990).

To compare the templates of $O$. nova and $E$. aediculatus, we set up similar experiments. Oligonucleotides complementary to different portions of telomerase RNA were tested for their ability to serve as primers in telomerase assays, and products were analyzed on sequencing gels (Fig. 7). In addition, we sought to distinguish between primers that were substrates because of complementarity to telomerase RNA and primers that were substrates because of their similarity to the 3 ' ends of telomeres. The more a complementary primer is extended into the putative template region, the more its $3^{\prime}$ end resembles a telomeric sequence. Therefore, several control oligonucleotides with a constant $3^{\prime}$ end and nonspecific sequence at the $5^{\prime}$ end were tested as well. The pattern of dark bands was taken to indicate the positioning of the primer with respect to telomerase RNA. We assumed that, as for Tetrahymena telomerase, the darkest bands of elongated products correspond to pausing of extension when the extreme $5^{\prime}$ end of the template is reached. The position of pausing is more difficult to evaluate for shorter than for longer products. This might be due to a more distributive mode of primer elongation by telomerase with short substrates/Collins and Greider 1993; Lee et al. 1993). However, the clear pausing site seen with longer products allows one to count nucleotides and thereby infer the precise extent of elongation even for the first elongation cycle.

For O. nova, all primers that were substrates showed an elongation pattern expected if their $3^{\prime}$ ends annealed between positions 43 and 45 (Fig. 7A). Oligonucleotides $\mathrm{O} 1$ and $\mathrm{O} 2$ were poor primers, with a pausing pattern that could not be explained by their $3^{\prime}$ ends annealing at position 50 and 49 , respectively, but could be explained by annealing to position 44 and 43 , respectively. [Oligonucleotides complementary to telomerase over their entire length were actually less efficient substrates than control oligonucleotides with the same $3^{\prime}$ end but a nonspecific $5^{\prime}$ end (cf. lanes 12 and 14; 16 and 18). Because the possibility of endogenous $\mathrm{RNaseH}$ activity in the extracts has not been evaluated, we base our conclusions primarily on the pattern of telomerase extension, not its efficiency.] For E. aediculatus (Fig. 7B), all substrates gave the elongation pattern expected if they annealed with their $3^{\prime}$ ends between positions 43 and 45 . With oligonucleotides E4 (lane 10), E4co (lane 12), and $\left(\mathrm{G}_{4} \mathrm{~T}_{4}\right)_{2}$ (lane 2) the first pause was seen after 9 nucleotides. This suggests that the template can be as long as 9 nucleotides. Oligonucleotide $\mathrm{E} 7$ has a $\mathrm{C}$ residue at its $3^{\prime}$ end and was an efficient substrate. We do not know whether the terminal $\mathrm{C}$ residue was removed by a nuclease prior to extension by telomerase. Many nucleases are present in the extract, and, for Tetrahymena, a nuclease activity has been found associated with telomerase /Collins and Greider 1993). As with O. nova, complementarity to telomerase RNA in the non-telomere-like $5^{\prime}$ half of a primer did not contribute to priming efficiency (cf. lanes 10 and $12 ; 14$ and $16 ; 18$ and 20$)$.

The experiments were also repeated with micromolar amounts of primer and extension was monitored by including $\left[\alpha{ }^{32} \mathrm{P}\right] \mathrm{dTTP}$ (data not shown). For O. nova, all tested primers became substrates under these conditions. Once again, on the basis of the pausing pattern, none of the substrates primed outside of the 8-base template region described above. For E. aediculatus E1 and E2 were not substrates even at high concentrations and E3 became a weak substrate. Also for E. aediculatus, all substrates showed an elongation pattern expected for annealing within the 9-base template, as above.

We conclude that the $O$. nova telomerase RNA template is at least 8 bases long, but unlikely to be much longer, because none of the tested substrates gave an elongation pattern that would have indicated its annealing with its $3^{\prime}$ end outside this region. The $5^{\prime}$ boundary is at position 37 , and the $3^{\prime}$ boundary is at or close to position 44. The E. aediculatus template region can be 9 bases long and is as well unlikely to be much longer. The $5^{\prime}$ boundary is at position 36 and the $3^{\prime}$ boundary is at or close to position 44 .

\section{Discussion}

Telomerase is essential for chromosome maintenance. Furthermore, as a ribonucleoprotein enzyme it is particularly intriguing from a mechanistic standpoint. The 
A
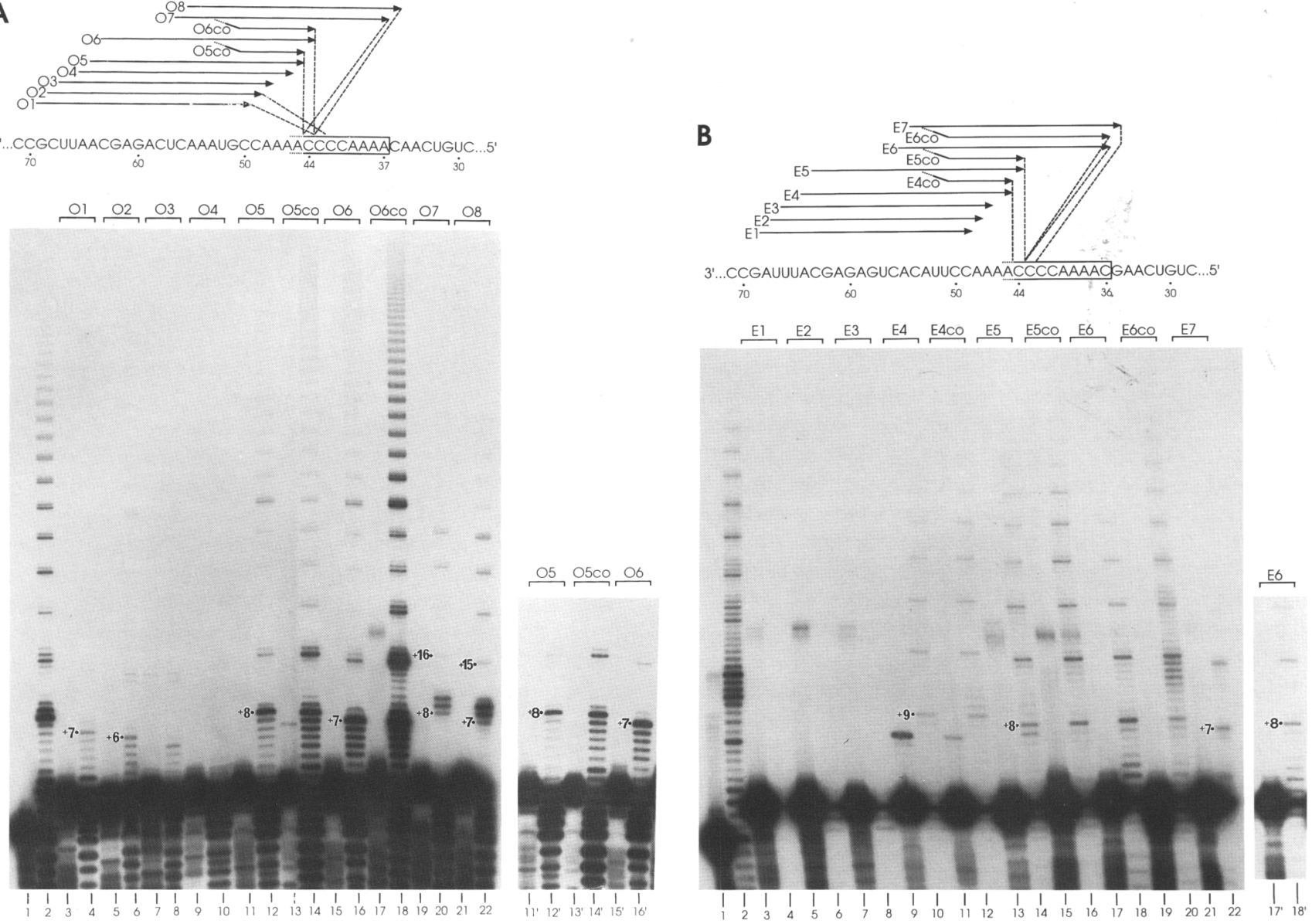

Figure 7. Telomerase assays with oligonucleotide substrates that are complementary to telomerase RNA and with control substrates. (A) Telomerase assay with O. nova nuclear extracts. Substrate oligonucleotides are represented in the upper part of the figure by arrows pointing $5^{\prime}$ to $3^{\prime}$. The telomerase RNA region to which they are complementary is shown underneath. The control oligonucleotides have shorter regions of complementarity indicated by the horizontal component of the bent arrows. The template region is indicated by the open box. The dashed lines connecting the arrowheads and the sequence indicate where individual substrates were positioned by telomerase during the first elongation cycle on the basis of the observed pausing pattern. Lanes $11^{\prime}-16^{\prime}$ are weaker exposures of lanes 11-16. Some of the pausing sites with the numbers of nucleotides added are indicated on the autoradiograph. Odd lanes contain oligonucleotides incubated without extract; even lanes, oligonucleotides incubated with extract. (Lanes 1,2$)$ telomerase assay with $\left(\mathrm{T}_{4} \mathrm{G}_{4}\right)_{2}$ as substrate. $(B)$ Telomerase assay with $E$. aediculatus nuclear extracts. Labeling is as in $A$. (Lanes 1,2$)$ telomerase assay with $\left(\mathrm{G}_{4} \mathrm{~T}_{4}\right)_{2}$ as substrate. Lanes $17^{\prime}$ and $18^{\prime}$ are weaker exposures of lanes 17 and 18 . Slower migrating bands, visible in some lanes with unreacted substrate (E4 and E4co) are of unknown nature. They represent such a small fraction of the oligonucleotide that they should not have contributed significantly to the banding pattern of products.

current work almost doubles the number of telomerase RNA sequences available. Despite the low extent of sequence identity between the telomerase RNAs of the hypotrichous and holotrichous ciliates, they are shown to share a common secondary structure. Thus, the structure model originally proposed by Romero and Blackburn (1991) has had its applicability extended, and at the same time has had many of its details confirmed or revised. In concomitant studies of telomerase activity, evidence is provided that the same telomeric repeat $\left(T_{4} G_{4}\right)$ can be synthesized from two different RNA template sequences $\left(\mathrm{A}_{4} \mathrm{C}_{4}\right.$ and $\left.\mathrm{CA}_{4} \mathrm{C}_{3}\right)$, one circularly permuted with respect to the other.

\section{Secondary structure and implications for function}

The sequence of one hypotrichous ciliate telomerase RNA (E. crassus) has been known for some time, but there was insufficient basis for aligning the sequence or proposing a secondary structure (Shippen-Lentz and Blackburn 1990). The phylogenetic comparison of telomerase RNAs from several hypotrichous ciliates now provides a common secondary structure model for this class. The tetrahymenine telomerase RNAs are shorter in length and are so diverged from those of the hypotrichs that the primary sequences cannot be aligned with confidence. It is therefore very encouraging that the bulk 
of the secondary structure is preserved. Most of the double helical segments are extended in the hypotrichous telomerase RNAs; however, their positions are preserved. The large evolutionary distance between the two classes is inferred further by the sequences of the small subunit ribosomal RNA genes (Fig. 1; Schlegel et al. 1991; Greenwood et al. 1991). This distance is of a magnitude similar to that separating animals and plants. Therefore the proposed structures might be common to all telomerase RNAs.

The secondary structure presented in Figure 4 is a minimal one. Many of the unpaired regions in the figure are likely to be engaged in some sort of pairing; further analysis is required to decipher these interactions. For example, the RNaseH cleavage experiments suggest that the region $5^{\prime}$ to the template region is not accessible for hybridization in the native RNP. In contrast, the template region and the adjacent region downstream are accessible to hybridization, suggesting that these regions are indeed unstructured. This is also supported by chemical modification analysis of telomerase RNA in vivo (A. Zaug and $\mathrm{T}$. Cech, unpubl.).

The model of the secondary structure is a static one. However, during telomere synthesis the primer and tem- plate must be repositioned with respect to each other (Fig. 8). One would expect that repositioning of telomeric primer and template must be accompanied by a conformational change of the enzyme and probably of the RNA. Romero and Blackburn (1991) speculated that a short conserved sequence of stem IV might alternately be engaged in base pairing with the flanking regions of stem II, and that this might cause a conformational change. These sequences, however, are not conserved in hypotrich telomerase RNAs, and base-pairing potential is not preserved.

A structure that is present in all telomerase RNAs and that might alternate between two conformations is the pseudoknot present downstream of the template. Pseudoknots are often thermodynamically metastable, existing in an equilibrium between the pseudoknot and a single stem-loop (Wyatt et al. 1990; Mans et al. 1992). When the pseudoknot form is present, the region downstream of the template might be held in a position that facilitates binding of primer and initiation of its elongation. The addition of a telomeric repeat to the primer might lead to destabilization of the pseudoknot, perhaps because of strain caused by formation of the duplex. This in turn might facilitate the repositioning of the template
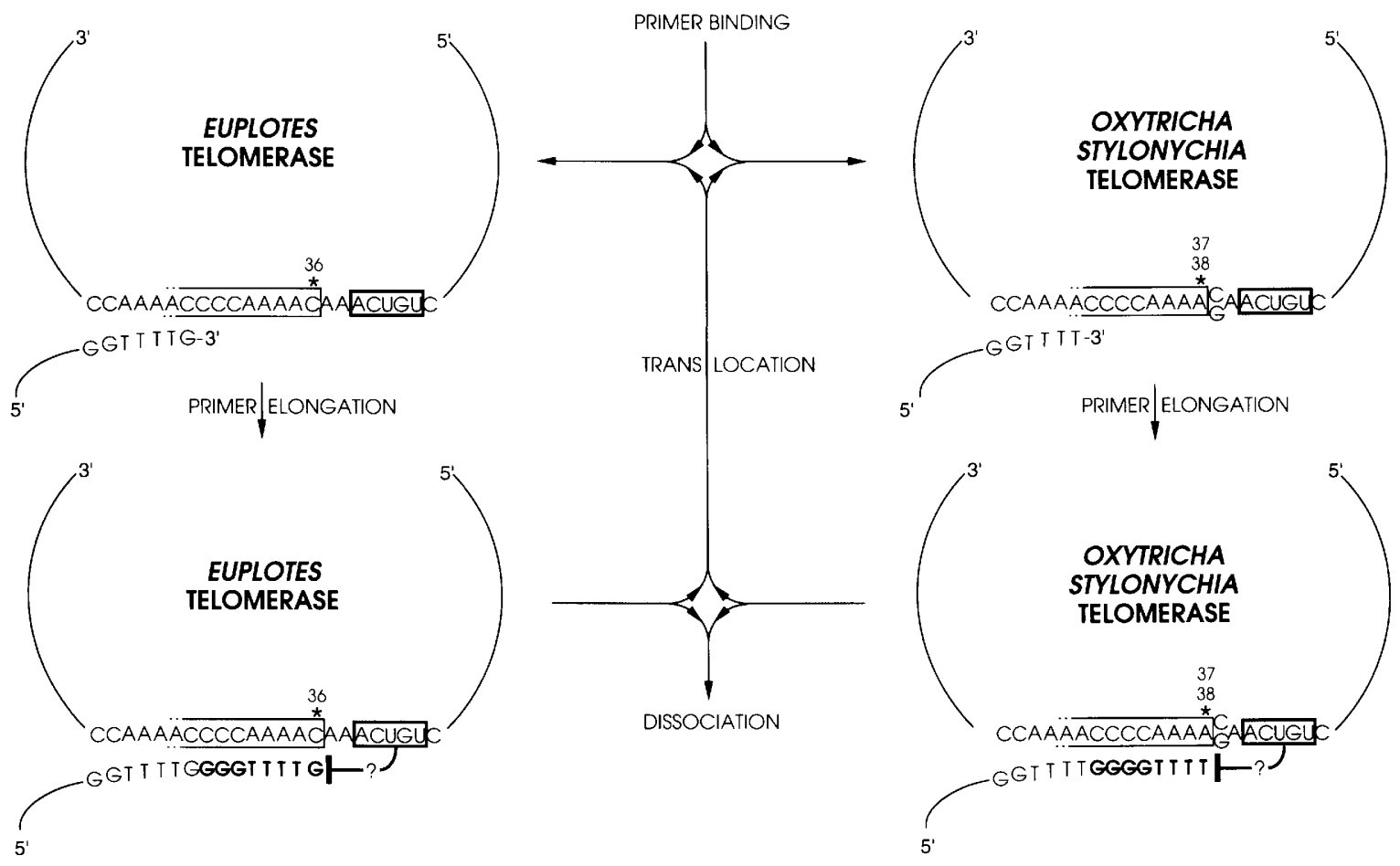

Figure 8. Model for primer elongation by telomerases of different hypotrichous ciliates. (Left) Euplotes telomerase; (right) Oxytricha and Stylonychia telomerases. The template region is highlighted by the open box and the conserved $5^{\prime}$-UGUCA-3' element by the closed box. Primer is bound by telomerase and aligned next to the template region, presumably assisted by complementary base pairing with the adjacent telomerase RNA sequence. Then the primer becomes elongated by the addition of one telomeric repeat. We speculate that the 5'-UGUCA-3' element might be engaged in an RNA or protein-RNA structure to provide a molecular cushion, preventing polymerization beyond the $5^{\prime}$ boundary of the template. Alternatively or in addition, this sequence might organize protein components of the active site relative to the template. After primer elongation, the primer is either released or becomes repositioned for the addition of another telomeric repeat. Euplotes adds 5'-GGGTTTTG-3' in each elongation cycle whereas Oxytricha and Stylonychia add 5'-GGGGTTTT-3'. 
and the primer. This model, however, remains without any experimental support.

\section{The template region}

Several lines of evidence indicate that the templates of Oxytricha and Stylonychia are circularly permuted relative to that of $E$. aediculatus. First, permuted template sequences are consistent with the conserved element $5^{\prime}$ (C)UGUCA-3' having a constant position relative to the template (Fig. 6A). Second, Stylonychia contains a G residue just upstream of the template, which would direct the misincorporation of $\mathrm{C}$ residues into telomeres. Third, on the basis of the pausing pattern of telomere DNA synthesis, the position at which translocation occurs in $E$. aediculatus is inferred to be shifted from the last $T$ in $5^{\prime}$-TTTTGGGG- 3 ' to the first $\mathrm{G}$ in the $5^{\prime}$-TTTTGGGG-3' telomeric repeats (Fig. 6B). Thus, we propose that Oxytricha and Stylonychia use as template the sequence 5'-AAAACCCC-3' and E. aediculatus uses 5'CAAAACCC-3'. Such a permutation might have evolved by a single insertion of a C-residue at the $5^{\prime}$ boundary of the Euplotes template or by deletion of this residue in a common progenitor of Oxytricha and Stylonychia.

For E. crassus it has been proposed that in the first elongation cycle the template can be as long as $12 \mathrm{nu}-$ cleotides (Shippen-Lentz and Blackburn 1990). An oligonucleotide that was complementary to telomerase RNA and that ended 13 nucleotides downstream of the $5^{\prime}$ boundary of the template was found to be a substrate in telomerase assays. In our experiments with E. aediculatus, however, control substrates with a nonspecific sequence at the $5^{\prime}$ end and the same telomere-like $3^{\prime}$ end were at least as efficiently elongated as substrates that were complementary to telomerase RNA over their entire length. The pausing patterns of elongated products suggest that some of the substrates aligned to telomerase RNA at positions different from those that would be expected if complementary sequences at the $5^{\prime}$ end of the substrate specified this process. Although we cannot distinguish the exact $3^{\prime}$ boundary of the template, none of the tested substrates appears to align outside of the 8-base template region that was used in later elongation cycles in O. nova. In $E$. aediculatus, three primers [E4, E4co, and $\left(\mathrm{G}_{4} \mathrm{~T}_{4}\right)_{2}$ in Fig. $\left.7 \mathrm{~B}\right]$ aligned so that nine nucleotides were used as template in the first elongation cycle. We see no evidence for a 12 -nucleotide template in E. aediculatus, even though the $\mathrm{RNaseH}$ experiments indicate that the region downstream from the template is accessible to hybridization. The continuation of the telomere-complementary sequence adjacent to the proposed template may align the primer, as has been proposed for Tetrahymena telomerase (Greider and Blackburn 1989; Autexier and Greider 1994).

An important caveat to all these experiments is that they were performed in crude nuclear extracts in which nucleases are present, as well as many other proteins that might influence the reaction. We therefore hope to address questions of telomerase RNA structure and function more thoroughly in a purified system.

\section{Materials and methods}

Growth of ciliates

O. nova, S. Iemnae, and E. aediculatus were grown as described previously (Swanton et al. 1980) under nonsterile conditions with Chlorogonium as the food source.

\section{Preparation of DNA from ciliates}

DNA samples from O. trifallax, S. mytilis, and E. eurystomus were obtained from D. Prescott. DNA was prepared from the other ciliates by harvesting cells as described below. DNA preparation followed Klobutcher et al. (1981) except DNA was purified by use of Qiagen-columns (Qiagen Inc.) instead of $\mathrm{CsCl}$ gradients.

\section{Polymerase chain reaction}

PCR was done in 50- $\mu$ l reactions containing $1 \mu \mathrm{g}$ of chromosomal DNA, $2 \mu \mathrm{m}$ primers, $0.2 \mathrm{~mm}$ dNTPs, $1 \times$ PCR buffer (Boehringer-Mannheim) and 2.5 units of Taq polymerase (Boehringer-Mannheim). DNA was first denatured for 4 min at $94^{\circ} \mathrm{C}$ and then amplified in 30 cycles, each involving denaturation for $1 \mathrm{~min}$ at $94^{\circ} \mathrm{C}$, annealing for $1 \mathrm{~min}$ at $48-65^{\circ} \mathrm{C}$, and polymerization for $2 \mathrm{~min}$ at $72^{\circ} \mathrm{C}$. Reactions were finished with a final polymerization step for $10 \mathrm{~min}$ at $72^{\circ} \mathrm{C}$. Products were analyzed and prepared on $4.5 \%$ NuSieve agarose gels (FMC BioProducts) and purified for subcloning as recommended by the supplier. Amplified products of low abundance were cut out from gels, melted, diluted at least 100 -fold and reamplified with 10-15 cycles.

\section{Cloning of telomerase RNA genes}

O. nova The $3^{\prime}$ region of the telomerase RNA gene was PCR amplified with a specific primer (T27) and a primer that can anneal at the telomeres of all macronuclear chromosomes (Telpr). To obtain the $5^{\prime}$ portion, nuclear RNA was reverse transcribed with the telomerase RNA specific primer T33, as follows. Nuclear RNA $(9 \mu \mathrm{g})$ was denatured for $5 \mathrm{~min}$ at $95^{\circ} \mathrm{C}$ in a volume of $20 \mu \mathrm{l}$, containing 4 pmoles of $\mathrm{T} 33,60 \mathrm{mM}$ Tris $-\mathrm{Cl} \mathrm{pH}$ $8.3,72 \mathrm{mM} \mathrm{NaCl}$ and $12 \mathrm{~mm}$ DTT. After annealing for $5 \mathrm{~min}$ at room temperature, $36 \mu \mathrm{l}$ of $50 \mathrm{~mm}$ Tris- $\mathrm{Cl} \mathrm{pH} \mathrm{8.3,10} \mathrm{mM} \mathrm{Mg-}$ acetate, $10 \mathrm{mM}$ DTT and 12 units of AMV reverse transcriptase (Life Science Inc.) were added and incubated for $30 \mathrm{~min}$ at $50^{\circ} \mathrm{C}$. The enzyme was heat inactivated for $5 \mathrm{~min}$ at $95^{\circ} \mathrm{C}$ and RNA was digested with $40 \mathrm{ng} / \mu \mathrm{l}$ RNase A. cDNA was purified by one phenol and one chloroform extraction and ethanol precipitated. It was dissolved in $2 \mathrm{ml}$ of $\mathrm{H}_{2} \mathrm{O}$, and unincorporated dNTPs were removed by concentrating the sample two consecutive times on a Centricon 30 column as recommended by the supplier (Amicon Division, W.R. Grace \& Co.l. One fourth of the cDNA was dG-tailed with terminal nucleotidyl transferase in $20 \mu \mathrm{l}$ containing $100 \mathrm{~mm} \mathrm{Na}$ cacodylate $\mathrm{pH} 7.2,0.2 \mathrm{~mm}$ mercaptoethanol, $2 \mathrm{mM} \mathrm{CoCl}_{2}, 0.1 \mathrm{~mm}$ DTT, $0.1 \mathrm{~mm}$ dGTP, 0.55 units of terminal nucleotidyl transferase (Du Pont) and incubated for $45 \mathrm{~min}$ at $37^{\circ} \mathrm{C}$. One fourth of the tailed cDNA was then PCR amplified with the telomerase-specific primer $\mathrm{T} 33$ and the $\mathrm{dG}$-tail-specific primer T15.

O. trifallax The 5' portion of the gene was PCR amplified with the template-specific primer T20 and the USE-specific primer 
T8T. The 3' region of the gene was amplified with the telomerase RNA-specific primer T25 and the telomere-specific primer Telpr. Finally, the entire transcribed region was amplified by PCR with 2 primers flanking the gene (T37 and T38).

$S$. lemnae The 5 ' portion of the gene was amplified with the telomerase RNA gene-specific primer T31 and the USE-specific primer T34T. The $3^{\prime}$ region of the gene to the telomere was amplified with the telomerase RNA gene-specific primer T24 and the telomere-specific primer Telpr. Finally, the entire transcribed region was amplified by PCR with 2 primers flanking the gene (T39 and T40).

S. mytilis The $5^{\prime}$ region of the gene was amplified with the telomerase RNA gene-specific primer T26 and the telomerespecific primer Telpr. The 3' region of the gene was amplified with the telomerase RNA gene-specific primer T24 and the telomere-specific primer Telpr. Finally, the entire transcribed region was amplified by PCR with 2 primers flanking the gene (T41 and T42).

E. aediculatus The $5^{\prime}$ portion of the gene was amplified with the telomerase RNA gene-specific primer T7 and the USE-specific primer $\mathrm{T} 34 \mathrm{~T}$. The $3^{\prime}$ region of the gene was amplified with the telomerase RNA-specific primer T12 and the telomere-specific primer Telpr. Finally, the entire transcribed region was amplified by PCR with the USE-specific primer T34T and a primer annealing downstream of the gene (T32).

E. eurystomus The $5^{\prime}$ portion of the gene was PCR amplified with the template-specific primer T20 and the USE-specific primer T8T. The $3^{\prime}$ portion of the gene was amplified with the template-specific primer $\mathrm{T} 5$ and $\mathrm{T} 7$, a primer that is specific for the $3^{\prime}$ end (T7 was based on the E. crassus telomerase RNA gene sequence). To obtain sequence information of the entire macronuclear chromosome, an inverse PCR strategy was employed. Chromosomal DNA was made blunt with T4 DNA polymerase (U.S. Biochemical) as described (Sambrook et al. 1989). Bluntended DNA $(2 \mu \mathrm{g} / \mathrm{ml})$ was ligated with $100 \mathrm{U} / \mathrm{ml}$ of T4 DNA ligase (Stratagene) overnight at $16^{\circ} \mathrm{C}$ and ethanol precipitated. Ligated DNA $(0.1 \mu \mathrm{g})$ was amplified by PCR in 40 cycles with the telomerase RNA gene-specific primers T13 and T14. Sequence analysis revealed that the obtained fragment had acquired a deletion in the 3 '-untranscribed trailer. Finally, the entire transcribed region was amplified by PCR with 2 primers flanking the gene (T35 and T36).

\section{DNA sequencing}

DNA fragments were subcloned into pBluescript $\mathrm{SK}+$ (Stratagene) and sequenced by the chain-termination method (Sanger et al. 1977) with a sequencing kit (U.S. Biochemical). The transcribed region of all telomerase RNA genes was verified by sequencing DNA fragments that were obtained from several independent PCR amplifications. The confirmed sequence data have been submitted to GenBank. Accession numbers are U10565 (E. aediculatus), U10566 (E. eurystomus), U10567 (O. nova), U10568 (O. trifallax), U10569 (S. lemnae), U10570 (S. mytilis|.

\section{3' End mapping of the O. nova telomerase RNA gene}

Nuclear RNA ( $3 \mu \mathrm{g}$ ) was poly(A) tailed with yeast poly(A) polymerase as described (Lingner and Keller 1993). Poly(A)-tailed nuclear RNA was reverse transcribed with the poly(A) tail-specific primer T17 under conditions described in the previous section. One-fourth of the cDNA was then amplified by PCR with $\mathrm{T} 17$ and the telomerase RNA gene-specific primer T27. Ampli- fied products were subcloned and subjected to sequence analysis.

\section{DNA oligonucleotides}

DNA oligonucleotides used in telomerase assays were gel-purified on denaturing polyacrylamide gels. Oligonucleotides were 5 '-end labeled in $10-\mu 1$ reactions containing 20 pmoles of oligonucleotide, 10 units of T4 polynucleotide kinase (New England Biolabs), $1 \mu \mathrm{l}$ of $10 \times$ buffer (New England Biolabs), $1 \mu \mathrm{l}$ $\left[\gamma^{-32} \mathrm{P}\right]$ ATP $(150 \mathrm{mCi} / \mathrm{ml}, 6000 \mathrm{Ci} / \mathrm{mmole}$, Du Pont $)$ for $30 \mathrm{~min}$ at $37^{\circ} \mathrm{C}$. Oligonucleotides were separated from unincorporated label over Sephadex-G25 chromatography. Sequences of DNA oligonucleotides are (the restriction sites used for subcloning are italicized): Rco, 5'-CGGGATCCTCGGCGGAAATCA/ CGTCAG-3'; R1, 5'-TGCTTTAAAGAGGAACCAGG-3'; R2, 5'-AATTGCTCTGAGTTTACGGT-3'; R3，5'-TTTACGGTTTTGGGGTTTTG-3'; R4， 5'-TTGACAGTGCTATGACTGAC3'; O1, 5'-CGAATTGCTCTGAGTTTACG-3'; O2, 5'-GAATTGCTCTGAGTTTACGG-3'; O3 5'-AATTGCTCTGAGTTTACGGT-3'; O4, 5'-TTGCTCTGAGTTTACGGTTT-3'; O5, 5'TGCTCTGAGTTTACGGTTTT-3'; O5co, 5'-GATCTCATCCGATTGGTTTT-3'; O6, 5'-GCTCTGAGTTTACGGTTTTG3'; O6co, 5'-TACTGTCTGCTGAGGTTTTG-3'; O7, 5'-GTTTACGGTTTTGGGGTTTT- ${ }^{\prime}$; O8, 5' $^{\prime}$-TTTACGGTTTTGGGGTTTTG-3'; E1，5'-TAAATGCTCTCAGTGTAAGG-3'; E2, 5'-AAATGCTCTCAGTGTAAGGT-3'; E3, 5'-AATGCTCTCAGTGTAAGGTT-3'; E4, 5'-TGCTCTCAGTGTAAGGTTTT3'; E4co, 5'-GATCTCATCCGATTGGTTTT-3'; E5, 5'-GCTCTCAGTGTAAGGTTTTG-3'; E5co, 5'TACTGTCTGCTGAGGTTTTG-3'; E6, 5'-TGTAAGGTTTTGGGGTTTTG-3'; E6co, 5'-ATAGTGGTTTTGGGGTTTTG-3'; E7, 5'-GTAAGGTTTTGGGGTTTTGC-3'; T5, 5'-CGGAATTCCAAACAAAACCCCAAA-3'; T7, 5'-CGGGATCCAAGATGAGAGGACAGC-3'; T8T, 5'-CGGGATCCTTTGACCCATAAA/TA/TA/TT-3'; T12, 5'-CGGGATCCGAGGTGAAAACCCCACAGCA-3'; T13, 5'CGGGATCCTTTCTCTCTATTGCCTGATT-3'; T14, 5'-CGGGATCCATTTGGGAGTAATCTCATAT-3'; T15, 5'-CGGGATCCC $_{16}$-3'; $^{\prime}$ T20, 5'-CGGGATCCNNGGTTTTGGGGTTTT-3'; T24, 5'-CGGGATCCTCGGCGGAAATCA/CGTCAG-3'; T25, 5'-CGGGATCCATAA/GCGCTGTCAACAAA-3'; T26, 5'-CGGGATCCTGACG/TGATTTCCGCCG-3'; T27, 5'-CGGGATCCAATTCGCCTGGTTCCTC-3'; T31, 5'-CGGGATCCGGAGAGAAA/GCTCTCAAAT-3'; T32, 5'-CGGGATCCATATTCAGTCTTAAAATCA-3'; T33, 5'-CGGGATCCTGC/ GCGGAA/GCCTCCTGGTT-3'; T34T, 5'-CGGGATCCNNNA/TGACCCATAAA/TA/TA/TT-3'; T35, 5'-CGGGATCCAAATCTGAATTTTCATAGAT-3'; T36, 5'-CGGGATCCTTTGCTTTTCGGTATAA-3'; T37, 5'-CGGGATCCGTATATCATTTCATGGCT-3'; T38, 5'-CGGGATCCAGTTGTAAAACGTAGCTG-3'; T39, 5'-CGGGATCCGCTTTAAATAATTTACAGT-3'; T40，5'-CGGGATCCAAAGATCCCAAGTCTCAT-3'; T41, 5'-CGGGATCCCAGTGTATTTCTAACCCT-3'; T42, 5'-CGGGATCCAGTTATATTGTGAATACTTAG-3'; Telpr, 5'-CGGGATCCCCAAAACCCCAAAA-3'.

\section{Preparation of nuclei and nuclear extracts}

For nuclei preparation, usually $2-4 \times 10^{7}$ cells were concentrated with $10-\mu \mathrm{m}$ Nitex filters and cooled on ice. The cells were centrifuged for $10 \mathrm{~min}$ at $2,800 \mathrm{~g}$ at $4^{\circ} \mathrm{C}$. All subsequent steps were done between $0-4^{\circ} \mathrm{C}$. Nuclei were isolated from the cell pellet as described (Zaug and Cech 1980) with slight modifications: All solutions contained $0.5 \mathrm{mM}$ PMSF, $0.5 \%$ thiodiglycol, and $0.5 \mathrm{mg} / \mathrm{ml}$ spermidine phosphate. The yield of nuclei was usually between 40 and $70 \%$. 
Nuclear extracts were made by resuspending the pelleted nuclei in 2 volumes of $50 \mathrm{mM}$ Tris- $\mathrm{Cl}(\mathrm{pH} 7.5), 0.45 \mathrm{M}$ potassium glutamate, $10 \mathrm{~mm} \mathrm{MgCl}_{2}, 1 \mathrm{~mm}$ DTT, $0.5 \mathrm{~mm}$ PMSF, 10\% glycerol, and $0.1 \% \mathrm{NP}-40$. The suspension was dounced with a glass homogenizer with 50 strokes and centrifuged for $15 \mathrm{~min}$ at $16,000 \mathrm{~g}$. Supernatants were collected, frozen in liquid $\mathrm{N}_{2}$, and kept at $-80^{\circ} \mathrm{C}$. Extracts made under these conditions were active for at least several months.

\section{Telomerase assays}

Telomerase assays were done in $40 \mu \mathrm{l}$ containing $0.5-1.5 \mu \mathrm{l}$ of extract, $50 \mathrm{~mm}$ Tris-Cl (pH 7.5), $50 \mathrm{~mm}$ K-glutamate, $10 \mathrm{~mm}$ $\mathrm{MgCl}_{2}, 1 \mathrm{mM} \mathrm{DTT}, 125 \mu \mathrm{M}$ dTTP, $125 \mu \mathrm{M} \mathrm{dGTP}$ and $\sim 0.2$ pmoles of $5^{\prime}-{ }^{32} \mathrm{P}$-labeled oligonucleotide substrate $(400,000$ $\mathrm{cpm}$ ). In Figure $3 \mathrm{C}$, the telomerase assay was performed with unlabeled $\left(\mathrm{T}_{4} \mathrm{G}_{4}\right)_{2}$ oligonucleotide substrate at $1 \mu \mathrm{M}$ in the presence of $2 \mu \mathrm{l}$ of $\left[\alpha^{-32} \mathrm{P}\right] \mathrm{dTTP}(10 \mathrm{mCi} / \mathrm{ml}, 800 \mathrm{Ci} / \mathrm{mmole}$, Du Pont) per reaction. The final concentration of dTTP was 0.31 $\mu \mathrm{M}$. Oligonucleotide primers were heat-denatured prior to addition. Reactions were assembled on ice and incubated for $30 \mathrm{~min}$ at $25^{\circ} \mathrm{C}$. Reactions were stopped by adding $200 \mu 1$ of $10 \mathrm{~mm}$ Tris- $\mathrm{Cl}(\mathrm{pH} 7.5), 15 \mathrm{~mm}$ EDTA, $0.6 \%$ SDS, and $0.05 \mathrm{mg} / \mathrm{ml}$ proteinase $\mathrm{K}$ and incubated for $30 \mathrm{~min}$ or longer at $45^{\circ} \mathrm{C}$. Following ethanol precipitation, products were analyzed on denaturating $8 \%$ polyacrylamide gels (Sambrook et al. 1989).

\section{Preparation of nuclear RNA}

RNA was purified from purified nuclei (see above) and from RNaseH-treated nuclear extracts with TRI-reagent (Molecular Research Center, Inc.) as recommended by the supplier.

\section{$R N a s e H$ treatment of extracts and RNA}

$\mathrm{RNaseH}$ digestions were performed in 12.5- $\mu$ l reactions containing $6 \mu \mathrm{l}$ of $O$. nova nuclear extract (or $0.9 \mu \mathrm{g}$ of nuclear RNA), 1 unit of $E$. coli RNaseH and $2.5 \mu$ l of $5 \times$ of buffer (both from U.S. Biochemical) and 100 pmoles of DNA oligonucleotide. After incubation for $30 \mathrm{~min}$ at $30^{\circ} \mathrm{C}$ the samples were divided into three aliquots for use in telomerase assays and Northern blotting.

\section{Northern blot analysis}

RNA (0.5 $\mu \mathrm{g}$ per lane or less) was resolved on $8 \%$ polyacrylamide gels and electroblotted onto a Hybond-N membrane (Amersham) (Sambrook et al. 1989). The blot was hybridized overnight in $10 \mathrm{ml}$ containing $4 \times$ SSC, $10 \times$ Denhardt's solution, $0.1 \%$ SDS, $50 \mu \mathrm{g} / \mathrm{ml}$ denatured herring sperm DNA, and $32.5 \mathrm{~mm}$ Tris- $\mathrm{Cl}$ ( $\mathrm{pH} 7.4$ ). After prehybridizing for $3 \mathrm{hr}, 2 \times 10^{6}$ $\mathrm{cpm}$ probe $/ \mathrm{ml}$ hybridization solution was added. The randomly labeled probe was a PCR-product that covered the entire $O$. nova telomerase RNA gene. The blot was washed with several buffer changes for $30 \mathrm{~min}$ in $2 \times \mathrm{SSC}, 0.1 \% \mathrm{SDS}$, and then for 1 $\mathrm{hr}$ in $0.1 \times \mathrm{SSC}, 0.1 \% \mathrm{SDS}$ at $45^{\circ} \mathrm{C}$.

\section{Acknowledgments}

We thank David Prescott for help and advice in growing ciliates and for the generous gift of cells and DNA samples; Julie Cooper, Guowei Fang, and Chris Rusconi for critical reading of the manuscript and discussion; Art Zaug for sharing unpublished data and for discussion; Doug Turner for evaluating the secondary structure prediction and for comments on the manuscript; Cheryl Grosshans for oligonucleotide synthesis; and Dorothy
Shippen for the suggestion to use potassium glutamate in nuclear extract preparations. This work was supported in part by grant GM28039 from the NIH. J.L. was supported by an EMBO long-term fellowship. T.R.C. is an Investigator of the Howard Hughes Medical Institute and an American Cancer Society Professor.

The publication costs of this article were defrayed in part by payment of page charges. This article must therefore be hereby marked "advertisement" in accordance with 18 USC section 1734 solely to indicate this fact.

\section{References}

Autexier, C. and C.W. Greider. 1994. Functional reconstitution of wild-type and mutant Tetrahymena telomerase. Genes \& Dev. 8: 563-575.

Blackburn, E.H. 1991. Structure and function of telomeres. Nature 350: 569-573.

- 1992. Telomerases. Annu. Rev. Biochem. 61: 113-129.

1993. Telomerase. In The RNA world (ed. R.F. Gesteland and J.F. Atkins), pp. 557-576. Cold Spring Harbor Laboratory Press, Cold Spring Harbor, New York.

Collins, K. and C.W. Greider. 1993. Tetrahymena telomerase catalyzes nucleolytic cleavage and non-processive elongation. Genes \& Dev. 7: 1364-1376.

Fang, G., J.T. Gray, and T.R. Cech. 1993. Oxytricha telomerebinding protein: Separable DNA-binding and dimerization domains of the $\alpha$-subunit. Genes \& Dev. 7: 870-882.

Gautheret, D., D. Konings, and R.R. Gutell. 1994. A major family of motifs involving G.A mismatches in ribosomal RNA. I. Mol. Biol. (in press).

Gilson, E., T. Laroche, and S.M. Gasser. 1993. Telomeres and the functional architecture of the nucleus. Trends Biochem. Sci. 3: 128-134.

Gottschling, D.E. and T.R. Cech. 1984. Chromatin structure of the molecular ends of Oxytricha macronuclear DNA: Phased nucleosomes and a telomeric complex. Cell 38: 501510 .

Gottschling, D.E. and V.A. Zakian. 1986. Telomere proteins: Specific recognition and protection of the natural termini of Oxytricha macronuclear DNA. Cell 47: 195-205.

Gray, J.T., D.W. Celander, C.M. Price, and T.R. Cech. 1991. Cloning and expression of genes for the Oxytricha telomerebinding protein: Specific subunit interactions in the telomeric complex. Cell 67: 807-814.

Greenwood, S.J., M.L. Sogin, and D.H. Lynn. 1991. Phylogenetic relationships within the class Oligohymenophorea, phylum Ciliophora, inferred from the complete small subunit rRNA gene sequences of Colpidium campylum, Glaucoma chattoni, and Opisthonecta henneguyi. I. Mol. Evol. 33: 163174.

Greider, C. 1991. Telomerase is processive. Mol. Cell. Biol. 11:4572-4580.

Greider, C.W. and E.H. Blackburn. 1985. Identification of a specific telomere terminal transferase acitivity in Tetrahymena extracts. Cell 43: 405-413.

- 1987. The telomere terminal transferase of Tetrahymena is a ribonucleoprotein enzyme with two kinds of primer specificity. Cell 51: 887-898.

. 1989. A telomeric sequence in the RNA of Tetrahymena telomerase required for telomere repeat synthesis. Nature 337: 331-337.

Hicke, B.J., D.W. Celander, G.H. MacDonald, C.M. Price, and T.R. Cech. 1990. Two versions of the genes encoding the 4l-kilodalton subunit of the telomere-binding protein of $\mathrm{Ox}$ - 
ytricha nova. Proc. Natl. Acad. Sci. 87: 1481-1485.

Jaeger, J.A., D.H. Turner, and M. Zuker. 1989. Improved predictions of secondary structure for RNA. Proc. Natl. Acad. Sci. 86: 7706-7710.

James, B.D., G.J. Olson, J. Liu, and N.R. Pace. 1988. The secondary structure of ribonuclease P RNA, the catalytic element of a ribonucleoprotein enzyme. Cell 52: 19-26.

Kipling, D. and H.J. Cooke. 1990. Hypervariable ultra-long telomeres in mice. Nature 347: 400-402.

Klobutcher, L.A., M.T. Swanton, P. Donini, and D.M. Prescott. 1981. All gene-sized DNA molecules in four species of hypotrichs have the same terminal sequence and an unusual $3^{\prime}$ terminus. Proc. Nat1. Acad. Sci. 78: 3015-3019.

Krämer, A., W. Keller, B. Appel, and R. Lührmann. 1984. The 5' terminus of the RNA moiety of U1 small nuclear ribonucleoprotein particles is required for the splicing of messenger RNA precursors. Cell 38: 299-307.

Lee, M.L. and E.H. Blackburn. 1993. Sequence-specific DNA primer effects on telomerase polymerization activity. Mol. Cell. Biol. 13: 6586-6599.

Lingner, J. and W. Keller. 1993. 3'-End labeling of RNA with recombinant yeast poly(A) polymerase. Nucleic Acids Res. 21: $2917-2920$.

Mans, R.M.W., M.H. van Steeg, P.W.G. Verlaan, C.W.A. Pleij, and L. Bosch. 1992. Mutational analysis of the pseudoknot in the tRNA-like structure of turnip yellow mosaic virus RNA. Aminoacylation efficiency and RNA pseudoknot stability. J. Mol. Biol. 223: 221-231.

Morin, G.B. 1989. The human telomere terminal transferase enzyme is a ribonucleoprotein that synthesizes TTAGGG repeats. Cell 59: 521-529.

Moyzis, R.K., J.M. Buckingham, L.S. Cram, M. Dani, L.L. Deaven, M.D. Jones, J. Meyne, R.L. Ratliff, and J.-R. Wu. 1988. A highly conserved repetitive DNA sequence, (TTAGGG), present at the telomeres of human chromosomes. Proc. Natl. Acad. Sci. 85: 6622-6626.

Ørum, H., H. Nielsen, and J. Engberg. 1992. Structural organization of the genes encoding the small nuclear RNAs U1 to U6 of Tetrahymena thermophila is very similar to that of plant small nuclear RNA genes. J. Mol. Biol. 227: 114-121.

Pace, N.R., D.K. Smith, G.J. Olson, and B.D. James. 1989. Phylogenetic comparative analysis and the secondary structure of ribonuclease P RNA-a review. Gene 82: 65-75.

Price, C.M. and T.R. Cech. 1987. Telomeric DNA-protein interactions of Oxytricha macronuclear DNA. Genes \& Dev. 1: 783-793.

Prowse, K.R., A.A. Avilion, and C.W. Greider. 1993. Identification of a nonprocessive telomerase activity from mouse cells. Proc. Natl. Acad. Sci. 90: 1493-1497.

Romero, D.P. and E.H. Blackburn. 1991. A conserved secondary structure for telomerase RNA. Cell 67: 343-353.

Sambrook, J., E.F. Fritsch, and T. Maniatis. 1989. Molecular cloning: A laboratory manual. Cold Spring Harbor Laboratory Press, Cold Spring Harbor, New York.

Sanger, F., S. Nicklen, and A.R. Coulson. 1977. DNA sequencing with chain-terminating inhibitors. Proc. Natl. Acad. Sci. 74: 5463-5467.

SantaLucia, J. Jr., R. Kierzek, and D.H. Turner. 1991. Stabilities of consecutive A.C, C.C, G.G, U.C, and U.U mismatches in RNA internal loops: Evidence for stable hydrogen-bonded $\mathrm{U} \cdot \mathrm{U}$ and $\mathrm{C} \cdot \mathrm{C}^{+}$pairs. Biochemistry 30: 8242-8251.

Schlegel, M., H.J. Elwood, and M.L. Sogin. 1991. Molecular evolution in hypotrichous ciliates: Sequence of the small subunit ribosomal RNA genes from Onychodromus quadricornutus and Oxytricha granulifera (Oxytrichidae, Hypotrichida, Ciliophora). J. Mol. Evol. 32: 64-69.
Shampay, J., J.W. Szostak, and E.H. Blackburn. 1984. DNA sequences of telomeres maintained in yeast. Nature 310: 154 157.

Shippen-Lentz, D. and E.H. Blackburn. 1990. Functional evidence for an RNA template in telomerase. Science 247: 546552.

Sogin, M.L., A. Ingold, M. Karlok, H. Nielsen, and J. Engberg. 1986. Phylogenetic evidence for the acquisition of ribosomal RNA introns subsequent to the divergence of some of the major Tetrahymena groups. EMBO I. 5: 3625-3630.

Swanton, M.T., A.F. Greslin, and D.M. Prescott. 1980. Arrangement of coding and non-coding sequences in the DNA molecules coding for rRNAs in Oxytricha sp. Chromosoma 77: 203-215.

ten Dam, E., A. van Belkum, and K. Pleij. 1991. A conserved pseudoknot in telomerase RNA. Nucleic Acids Res. 19: 6951 .

Watson, J.D. 1972. Origin of concatemeric T7 DNA. Nature New Biol. 239: 197-201.

Woese, C.R. and N.R. Pace. 1993. Probing RNA structure, function, and history by comparitive analysis. In The RNA world (eds. R.F. Gesteland and J.F. Atkins), pp. 91-117. Cold Spring Harbor Laboratory Press, Cold Spring Harbor, New York.

Wyatt., J.R., J.D. Puglisi, and I. Tinoco Jr. 1990. RNA pseudoknots. Stability and loop size requirements. I. Mol. Biol. 214: 455-470.

Yu, G.L., J.D. Bradley, L.D. Attardi, and E.H. Blackburn. 1990. In vivo alteration of telomere sequences and senescence caused by mutated Tetrahymena telomerase RNAs. Nature 344: 126-132.

Zahler, A.M. and D.M. Prescott. 1988. Telomere terminal transferase activity in the hypotrichous ciliate Oxytricha nova and a model for replication of the linear DNA molecules. Nucleic Acids Res. 16: 6953-6972.

Zakian, V.A. 1989. Structure and function of telomeres. Annu. Rev. Genet. 23: 579-604.

Zaug, A.J. and T.R. Cech. 1980. In vitro splicing of the ribosomal RNA precursor in nuclei of Tetrahymena. Cell 19: 331338.

Zuker, M. 1989. On finding all suboptimal foldings of an RNA molecule. Science 244: 48-52. 


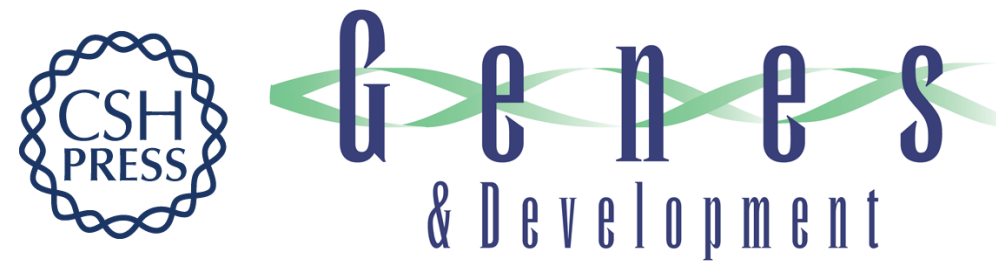

\section{Telomerase RNAs of different ciliates have a common secondary structure and a permuted template.}

$\mathrm{J}$ Lingner, L L Hendrick and T R Cech

Genes Dev. 1994, 8:

Access the most recent version at doi:10.1101/gad.8.16.1984

References This article cites 45 articles, 14 of which can be accessed free at:

http://genesdev.cshlp.org/content/8/16/1984.full.html\#ref-list-1

License

Email Alerting

Service

Receive free email alerts when new articles cite this article - sign up in the box at the top right corner of the article or click here.

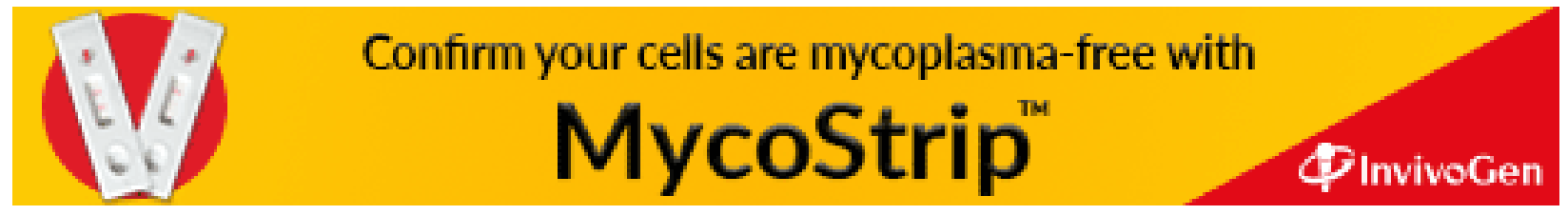

